Comparative Philosophy Volume 7, No. 1 (2016): 20-38

Open Access / ISSN 2151-6014

www.comparativephilosophy.org

\title{
MORAL SAINTS, HINDU SAGES, AND THE GOOD LIFE
}

\author{
CHRISTOPHER G. FRAMARIN
}

\begin{abstract}
Roy W. Perrett argues that the Hindu sage, like the western moral saint, seems precluded from pursuing non-moral virtues, interests, activities, relationships, and so on for their own sakes. A life devoid of every such pursuit seems deficient. Hence, the Hindu sage seems to forsake the good life. In response, I adapt a reply that Vanessa Carbonell offers in the context of the moral saint. The Hindu sage might pursue non-moral virtues, interests, activities, relationships, and so on for their own sakes, so long as his motivation to pursue mokșa is read de re rather than de dicto. Indeed, this reply is more convincing in the case of the Hindu sage than it is in the case of the moral saint.
\end{abstract}

Keywords: welfare, well-being, the good life, renunciation, asceticism, Hindu sage, moral saint, Susan Wolf

\section{INTRODUCTION}

Classical Hindu texts tend not to outline their conceptions of welfare (in the sense of personal well-being) explicitly. ${ }^{1}$ But since they tend to count the life of the sage as exceedingly good for him, it makes some sense to think that a theory of the good life

FRAMARIN, CHRISTOPHER G.: Associate Professor, Department of Philosophy \& Department of Classics and Religion, University of Calgary, Canada. Email: chris.framarin @ucalgary.ca

\footnotetext{
${ }^{1}$ There seem to be exceptions to this general claim. The first is the Bhagavadgit $\bar{a}$ (Gìtā), in which Krșna enjoins Arjuna to act for the sake of lokasamgraha - which might be understood as something like the welfare of the world (Bhagavadgit $\bar{a}$ 3.20, 3.25). The notion of world welfare, however, is distinct from the notion of personal, individual welfare.

Nonetheless, the two are presumably related. The welfare of the world presumably depends at least in part on how well individuals fare within that world. If this is right, then any analysis of world welfare in the Gìtā or elsewhere will depend at least in part on an accurate analysis of personal welfare. This is another reason to think that the arguments of this paper have broad importance. Another apparent exception is the Arthaśāstra. The Arthaśāstra discusses something akin to world welfare as well (or kingdom welfare), as a means to the welfare of the king. Much work would need to be done, however, to infer a more general theory of the good life from these discussions.
} 
might be inferred from his example. It makes some sense to think that these texts take a life to be good for the person whose life it is insofar as it exemplifies those characteristics that make the sage's life good for the sage.

The plausibility of any such theory will depend, at least in part, on whether the Hindu sage does indeed live the good life. One way to assess whether the sage does indeed live the good life is to consider objections to the claim that his life is good for him.

The objection that I consider in this paper is an objection that Roy W. Perrett adapts from Susan Wolf. The objection states that the moral ideal of the Hindu sage, who dedicates himself single-mindedly to the pursuit of the highest good of moksa (liberation), is inconsistent with the pursuit of non-moral virtues, interests, activities, relationships, and so on for their own sakes. A life entirely devoid of every such pursuit seems deficient. So the life of the Hindu sage seems deficient. I call this the 'Precluded Pursuits Objection.'

One seemingly promising reply to the Precluded Pursuits Objection claims that mokșa is a non-moral end. If mokșa is a non-moral end, then it is false that the sage's single-minded pursuit of mokșa precludes his pursuit of non-moral ends. Nonetheless, the sage's single-minded pursuit of moksa still seems to preclude his pursuit of nonmoral virtues, interests, activities, relationships, and so on for their own sakes. He only pursues these things insofar as they contribute toward the attainment of moksa. His life still seems deficient for this reason.

This initial reply can be supplemented, however, by a reply that Vanessa Carbonell offers to Wolf's objection in the context of the moral saint. Carbonell argues that Wolf mistakenly characterizes the moral saint's motivation to improve the general welfare as a de dicto, rather than a de re motivation. If the saint is motivated to improve the general welfare de dicto, then he has only one underived motivation: namely, the motivation to improve the general welfare. This is problematic. If he is motivated to improve the general welfare de re, however, then he might have a distinct, underived motivation to bring about each of the ends that contribute to the improvement of the general welfare. Consequently, he might pursue each of these ends for its own sake.

Carbonell's reply to the Precluded Pursuits Objection fails in the case of the moral saint. Even if the moral saint pursues ends other than the improvement of the general welfare for their own sakes, and even if some of these ends are non-moral in some sense, the saint's commitments to these non-moral ends are shallow and contingent. The saint must abandon them as soon as they no longer contribute sufficiently to the improvement of the general welfare. His life seems deficient for this reason.

The Hindu sage's pursuit of ends that contribute to the attainment of moksa, in contrast, are not shallow in this way, because their relations with the end of moksa are necessary and enduring. Hence, the Hindu sage ideal avoids the Precluded Pursuits Objection. 


\section{SAGES AND THE GOOD LIFE}

I begin with the assumption that many Hindu texts and traditions take the sage to live an especially good life. To say that the sage lives a good life in this sense is to say that he lives well, and to say that he lives well is to say that he lives a life that is intrinsically good for him.

If the sage's life is intrinsically good for him, then it is good independently of how good it is for others, and independently of how good it is as a means to some future life. This is not to say that the sage's life is not good in these other senses as well. It is just to say that these are not the senses of the good life with which I am concerned in this paper. ${ }^{2}$

If certain Hindu texts and traditions take the life of the sage to be exceedingly good for him, then it might turn out that the inference from Hindu conceptions of sagehood to an account of the good life is straightforward. A person's life might be intrinsically good for him insofar as it exemplifies those characteristics that make the life of the sage good for the sage.

If the sage's life is good for him because it contains a good deal of joy, for example, then presumably episodes of (relevantly similar) joy contribute to the intrinsic value of a life more generally. If the sage's life is good for him because he is free (in some sense to be specified), then presumably (relevantly similar) episodes of freedom contribute to the intrinsic value of a life in general, and so on.

Now of course, there is more than one Hindu conception of sagehood, and even after these conceptions are broadly categorized, they are characterized in different ways by different texts and traditions. ${ }^{3}$ I mean to limit myself to the samnyāsin (renunciate) and karmayogin (disciplined actor) ideals in particular. Both are found in the Mahābhärata, ${ }^{4}$ the Bhagavadgitā being not only the locus classicus of the karmayogin ideal, but also a source for criticism of the samnyāsin ideal. The Samnyāsa Upanișads detail the behaviors and intentions of the samnyyāsin in some of the most detail, and the Yogaśāstra ${ }^{5}$ offers one of the earliest and most thorough justifications for his mode of life, in the form of a wide ranging metaphysics, moral

2 The sage's life might be extrinsically (or instrumentally) good for these reasons. The fact that the sage's life benefits others might also make it morally good (Feldman 2004, 8-9).

${ }^{3}$ For a sample of the complexity of these categories among contemporary Hindu traditions, see Richard Burghart (1983, 641-44).

${ }^{4}$ Peter Hill cites a number of passages from the Śantiparvan of the Mahābhārata that advocate the saṃnyāsin ideal. They include Śāntiparvan 169, 207-208, 212, 222, 284, 342 (Hill 2008, 335, fn 40). Gregory Bailey points out that Yudhișțira himself reflects saṃnyāsin values,

for throughout the epic [Yudhișthira] seeks to renounce the kingship in favour of an ascetic life in the forest... Such a yearning for the renouncer's life is consistent with his yogic affiliations which are present right from his gestation because his father, Dharma, took the form of a yogin to have intercourse with his mother, Kuntī (Bailey 1985, 119-20).

${ }^{5}$ The title Yogaśāstra refers to both the Yogasūtra and Yogabhāṣya. As Philipp Maas argues, these texts were probably composed at the same time, by a single author, contrary to common opinion (Maas 2013). 
psychology, and so on. So I proceed with conceptions of the samnyasin and karmayogin described in these texts, among others, in mind.

If a theory of the good life is derived from a model of Hindu sagehood, then the plausibility of the theory will depend, at least in part, on whether the life of the Hindu sage is good for him. So one way to assess the plausibility of any such theory is to evaluate whether the life of the sage is good for him in the first place. And one way to evaluate whether the life of the sage is good for him in the first place is to consider objections to the claim that the sage's life is good for him.

\section{THE PRECLUDED PURSUITS OBJECTION}

I adopt the current objection to the claim that the Hindu sage lives the good life from Roy W. Perrett. Perrett adapts this objection from Susan Wolf's well-known paper, "Moral Saints." Wolf's version of the objection is aimed at western moral saint ideals. She takes the basic objection to apply not only to the moral saint ideal that might be derived from so-called "common sense morality," but also from modern moral theories like utilitarianism and the philosophy of Kant. For the sake of simplicity in what follows, I focus on the version of this argument that Wolf levels against the moral saint of common sense morality.

Wolf argues that the moral saint ideal is not worth pursuing because it requires the moral saint to abandon too much of what makes life worth living. She claims that according to common sense morality, the life of the moral saint is "dominated by a commitment to improving the welfare of others or of society as a whole" (Wolf 1982, 420). To say that this commitment "dominates" the saint's life is to say that it invariably overrides all other considerations, leaving little to no room for the pursuit of non-moral ends. This means that the saint is unable to cultivate non-moral virtues, interests, activities, relationships, and so on. ${ }^{6}$

The moral saint generally cannot cultivate his interest in gourmet cooking or interior design, for example. He cannot learn the oboe, work at improving his backhand, or spend time reading Victorian novels (Wolf 1982, 421-22), since these activities are generally not the best means to maximally improving the welfare of others.

These pursuits might seem whimsical, and the fact that the saint must abandon them trivial, but the same reasons that count against learning the oboe seem to count against pursuing a graduate degree, mastering a vocation, cultivating deep

\footnotetext{
${ }^{6}$ Wolf generally emphasizes the importance of pursuing or cultivating these non-moral ends, rather than accomplishing or "having" them (although see Wolf 1982, 426), since it is generally their pursuit rather than their attainment that conflicts with maximizing the general welfare. Another reason to emphasize their cultivation is that many of the non-moral ends that she has in mind cannot be attained in any final way, and hence, might require persistent cultivation.

This should not be taken to imply that Wolf does not count some degree of success in these pursuits to be essential to the good life. In what follows, I also tend to talk about the pursuit of nonmoral ends as opposed to their attainment, but I too do not mean to deny that some degree of success in these pursuits might also be essential to the good life. To repeatedly qualify claims about the pursuit of non-moral ends in this way, however, would be unnecessarily clumsy.
} 
interpersonal relationships, and so on. At any given time, a person probably better serves the general welfare by working more directly to alleviate hunger, illiteracy, illness, and violence (Wolf 1982, 428, Cf. Williams 1973, 115-18). A life entirely devoid of every such pursuit, however, seems deficient.

Wolf admits that there might be circumstances in which the pursuit of non-moral ends maximally improves the welfare of others. "It may be," for example, "that a good golf game is just what is needed to secure that big donation from Oxfam" (Wolf 1982, 425). Even in these kinds of cases, however, the moral saint does not pursue non-moral virtues, interests, activities, and so on for their own sakes - independent of their relations to improving the general welfare. "[F] these interests and skills can be given at best the status of happy accidents - they cannot be encouraged for their own sakes as distinct, independent aspects of the realization of human good" (Wolf 1982, 425). The moral saint pursues these things if he does at all - only as means to, or as constituents of the further or broader end of improving the general welfare (Wolf 1982, 429). A life entirely devoid of the pursuit of such ends for their own sakes, however, seems deficient.

Wolf adds that when a person values things only under a more general description - such as under the general description of 'contribution to the general welfare' - it suggests "not only a weakness but a shallowness of appreciation of the aspects in question" (Wolf 1982, 429-30). If a person values a personal relationship, for example, only as a means to the general welfare, then presumably he abandons the relationship as soon as it is no longer the optimum means to this end.

The same will be true if he values the relationship only as a constituent of the general welfare. Once some more valuable, but incompatible constituent (or means) is available, he should abandon the relationship. This presumably undermines his capacity to participate in the relationship fully, and probably undermines his capacity to have certain types of relationships altogether. The same might be said of his commitments to pursue non-moral virtues, interests, activities, and so on. A life in which every non-moral commitment of this sort is contingent and shallow, however, seems deficient. ${ }^{7}$ In what follows, I refer to this argument as the 'Precluded Pursuits Objection'.

${ }^{7}$ Peter Railton replies to what might seem like a similar objection.

It might be objected that one cannot really regard a person or a project as an end as such if one's commitment is in this way contingent or overridable. But were this so, we would be able to have very few commitments to ends as such. For example, one could not be committed to both one's spouse and one's child as ends as such, since at most one of these commitments could be overriding in the case of conflict. It is easy to confuse the notion of a commitment to an end as such (or for its own sake) with that of an overriding commitment (Railton 1984, 141).

The objection that I am concerned with here, however, is not that the pursuit of every end for its own sake must inevitably override all other considerations. Instead, the objection is that a life in which every pursuit other than the pursuit of the improvement of the general welfare is entirely contingent on its relations to some further (or broader) end is deficient - at least in those cases where the relations are subject to regular change, as they seem to be in the case of the moral saint. 
Perrett considers whether a version of the Precluded Pursuits Objection might be leveled against the Hindu sage ideal. He first formulates the objection in the context of the Bhagavadgīta (Gìt $\bar{a})$. He says,

[t]he ideal of the moral saint which the Gitta presents us with is not one to which we should reasonably aspire since the single-minded pursuit of such an ideal would involve giving up too much of what makes a life worth living. Even if we could achieve such a standard, to do so would be undesirable (Perrett 1998, 30).

This formulation of the objection suggests that Perrett means to consider whether a version of the Precluded Pursuits Objection applies to the karmayogin ideal of the Gìtā in particular.

Perrett eventually broadens his focus, however, to include other texts and traditions, including the Dharmaśāstras, Sāṃkhya, Yoga, Advaita Vedānta, and others (Perrett 1998, 33-34), some of which do not advocate the karmayogin ideal. Within this broader context, Perrett formulates the objection again.

[I]s not the cost of pursuing liberation too high? For if the only way to protect ourselves from [the] suffering [of rebirth] is to practise yoga and attain mokșa [liberation], then have we not paid far too much for what we can gain (Perrett 1998, 40)?

This passage suggests two things. First, it suggests that on Perrett's adapted version of the Precluded Pursuits Objection, it is the pursuit of moksa that threatens to override all other considerations. The Hindu sage's pursuit of moksa, on this version of the argument, parallels the moral saint's pursuit of the general welfare.

Second, it implies that this version of the Precluded Pursuits Objection might be leveled against any conception of the Hindu sage, so long as it claims that the sage pursues mokșa single-mindedly. Hence, the objection might be leveled against either the karmayogin or the samnyyāsin ideal.

If this objection parallels Wolf's Precluded Pursuits Objection, then the objection must run roughly as follows. The Hindu sage single-mindedly pursues moksa. ${ }^{8}$ This moral commitment ${ }^{9}$ overrides all non-moral considerations, and hence, precludes the pursuit of non-moral virtues, interests, activities, relationships, and so on for their own sakes. A life entirely devoid of every such pursuit seems deficient. Hence the Hindu sage seems to forsake the good life.

If the Hindu sage forsakes the good life, then the life of the sage cannot be a model on which to base a theory of the good life. If the sage's life is not good for him in the first place, then no theory of the good life that is inferred from the model of the Hindu sage will be plausible.

\footnotetext{
${ }^{8}$ As Bailey points out, the nivrtti "ideology and associated life style is quite simply attuned to the attainment of moksa. Everything is rendered subservient to this one goal" (Bailey 1983, 20). This suggests that this central claim of the Precluded Pursuits Objection is at least true of the samnyāsin.

${ }^{9}$ It might seem strange to take the sage's commitment to attain moksa as a moral commitment. See below.
} 


\section{CLARIFICATION OF THE PRECLUDED PURSUIT OBJECTION}

Before I consider possible replies to the Precluded Pursuits Objection to Hindu Sage Ideals, I want to offer some clarifications of the objection itself. First, the Precluded Pursuits Objection states that the life of the Hindu sage is deficient because the sage's single-minded pursuit of moksa, in particular, precludes his pursuit of non-moral virtues, interests, activities, relationships, and so on for their own sakes. This is the objection that I evaluate in the rest of this paper.

It might be, however, that there are other reasons to think that the sage is precluded from pursuing non-moral virtues, interests, and so on. One such objection states that the Hindu sage does not pursue non-moral virtues, interests, activities, relationships, and so on for their own sakes because he does not desire earthly things for their own sakes. If the sage does not desire earthly things for their own sakes, and if desires motivate actions, then presumably the sage does not pursue earthly things for their own sakes. And if the sage does not pursue earthly things for their own sakes, then he does not pursue non-moral virtues, interests, and so on for their own sakes.

I consider this and other related objections elsewhere. ${ }^{10}$ For now, however, I am concerned with whether the sage's single-minded pursuit of moksa in particular implies that he does not pursue non-moral virtues, interests, and so on for their own sakes.

Second, the Precluded Pursuits Objection does not state that a person must pursue non-moral virtues, interests, activities, relationships, and so on for their own sakes in order to live the good life. It only says that a person who does not pursue any of these things for their own sakes does not live the good life. This is consistent with allowing that a person might not pursue non-moral virtues for their own sakes, and still live the good life. It is consistent with allowing that a person might not pursue non-moral relationships for their own sakes, and still live the good life, and so on.

The samnyāsin might seem straightforwardly precluded from pursuing non-moral relationships for their own sakes. He is consistently characterized as abandoning family, friends, and acquaintances. He is even characterized as avoiding places where he might be recognized. This, by itself, however, does not entail that he is subject to the Precluded Pursuits Objection.

The samnyāsin is only subject to the Precluded Pursuits Objection if he is precluded from the pursuit of non-moral virtues, interests, activities, and so on as well. The same will be true of the karmayogin. The thought, then, is not that a person must pursue all of the things that the Hindu sage seems precluded from pursuing in order to live the good life. The point is that he must pursue at least some of them.

\footnotetext{
${ }^{10} \mathrm{My}$ tentative view is that this alternative version of the objection can be avoided, so long as the pursuit of non-moral virtues, interests, and so on might be motivated by states other than desires. This seems plausible in light of the distinction between desires and 'mere purposes' for which I argue elsewhere (Framarin 2009).
} 
Consequently, the Precluded Pursuits Objection does not state that a person must pursue any particular non-moral virtue, interest, activity, relationship, and so on. It does not say, for example, that a person must pursue the non-moral virtues involved in gourmet cooking or interior design. It does not claim that a person must pursue a relationship with a parent, spouse, or child in particular. All it says is that a person must pursue some of those things that might be classified as non-moral virtues, interests, activities, relationships, and so on.

\section{A REPLY TO THE PRECLUDED PURSUITS OBJECTION}

There are a number of replies that might be offered to the Precluded Pursuits Objection. ${ }^{11}$ Perrett replies that the Hindu sage ideals are supererogatory, and hence, not strictly required. This reply seems to conflate two distinct objections, however. ${ }^{12}$ The first objection is the Precluded Pursuits Objection, which, again, claims that the Hindu sage forsakes the good life in his pursuit of liberation.

The second objection is the Demandingness Objection, which claims that a certain moral theory (or system) requires too much of its adherents. As Garrett Cullity points out, "[w]hen moral philosophers first started talking of 'the problem of demandingness', they were referring to an alleged problem concerning how much is demanded of anyone attempting to do what certain moral theories claim is morally required of us" (Cullity 2009, 8). To claim that certain standards are supererogatory, and hence, not required, then, might be a convincing reply to the Demandingness Objection (Hooker 2009, 151-52). It is not convincing, however, as a reply to the Precluded Pursuits Objection, just because the Precluded Pursuits Objection does not charge that the demanding standards are required. ${ }^{13}$

An alternative reply states that there is good reason to think that in pursuing his own moks a, the sage pursues an end that is at least partly non-moral. ${ }^{14}$ The attainment

\footnotetext{
${ }^{11}$ Some replies might admit that the absence of these pursuits in the life of the sage constitutes a prima facie diminution of his welfare, but then insist that this loss is compensated by other gains (or other precluded losses). I consider replies of this sort elsewhere.

Another possible reply points out that in the classical formulation of the áśrama system, a person typically becomes a samnnyāsin in old age. If he has spent the earlier parts of his life in pursuit of nonmoral virtues, interests, and so on for their own sakes, the intuition that his life is deficient is significantly weakened. (My thanks to Roopen Majithia for this suggestion.) This reply might not work in the case of the karmayogin, however, since the karmayogin ideal is not reserved for old age. It also might not work in those cases for which nearly every text allows an exception - cases in which a person acquires the detachment suited to the samnyāsin before old age (see, for example, Nāradaparivrājaka Upaniṣad 138-39, 149, Paramahaṃsaparivrājaka Upaniṣad 278).

${ }^{12}$ My thanks to Stephen Harris for bringing this important point to my attention.

${ }^{13}$ Charles Goodman (Goodman 2009, 133-39) offers a reply to the Demandingness Objection as it might apply to the Buddhist bodhisattva ideal that parallels Perrett's reply. He also explicitly distinguishes this objection from the Precluded Pursuits Objection, however, to which he offers a separate reply (Goodman 2009, 141-44). Stephen Harris considers the Demandingness Objection in the Buddhist context as well, but offers a distinct reply (2014, 32-64).

${ }^{14}$ That mokșa is at least partly a non-moral end seems clear for the reasons I outline just below. This is presumably why Louis Dumont describes the samnyāsin as “an end for himself” (Dumont 1966, 235).
} 
of mokșa amounts to the end of rebirth. Suffering pervades rebirth. Hence, in attaining moksa, the sage eliminates his own suffering (Perrett 1998, 53). If the state of moksa is also positively pleasurable - as most texts and traditions claim - then the sage is further benefitted.

If the state of moksa is beneficial to the sage, however, then presumably he pursues moksa at least in part for this reason. It is hard to imagine that the sage does not at least see the elimination of his own suffering as a direct reason to attain moksa. And insofar as he is motivated by this fact, he is motivated by prudential, non-moral reasons. Hence he pursues at least one non-moral end for its own sake - namely, his own moksa. So it is false that the Hindu sage is precluded from pursuing non-moral ends for their own sakes.

This reply should seem unsatisfying, however. The Precluded Pursuits Objection charges that the Hindu sage's single-minded pursuit of mokșa precludes his pursuit of a wide range of non-moral ends, the pursuit of at least some of which is essential to the good life. These non-moral ends include non-moral virtues, interests, activities, relationships, and so on. Even if the sage pursues a non-moral end in pursuing mokșa, however, his single-minded pursuit of mokșa still seems to preclude his pursuit of non-moral virtues, interests, activities, relationships, and so on for their own sakes, just because mokșa is the only non-moral end that the sage pursues for its own sake.

In discussing Wolf's version of the Precluded Pursuits Objection, I mentioned that Wolf allows that the moral saint might pursue non-moral virtues, interests, activities, relationships, and so on. She insists, however, that if the moral saint pursues these things, he pursues them only as means to the general welfare and/or as constituents of the general welfare. He fails to pursue these things for their own sakes. This, Wolf claims, makes his life deficient.

The same considerations suggest that the life of the Hindu sage is deficient. Even if the Hindu sage pursues a wide range of things, the fact that he pursues them only as means to and/or as constituents of mokșa implies that he does not pursue them for their own sakes. This seems true, however, whether mokșa is a moral or a non-moral end.

If mokșa is a non-moral end, then those things that the sage pursues only as means to and/or as constituents of mokșa might be non-moral ends as well. These ends might be diverse. Many Hindu texts and traditions take equanimity, for example, to be among the virtues that the Hindu sage cultivates (Yogaśāstra 2.55, Bhagavadgittā 2.56, and so on). So the sage pursues non-moral virtue. Many Hindu texts and traditions assume that the sage cultivates a relationship with a guru as a means to attaining mokṣa (Nāradaparivrājaka Upaniṣad 157, Brhat-Samnnyasa Upanișad 254). So the sage pursues non-moral relationships.

It is not enough, however, to note that the sage cultivates non-moral virtues, relationships, and so on. If the sage does indeed pursue moksa single-mindedly, then

I add the word 'primarily' to leave open the possibility that the sage's pursuit of mokșa is also the pursuit of a moral end. This might be the case if mokssa is an embodied state of benevolence, as many contemporary authors argue (for example, Whicher 1998; Fort 1998). 
his pursuit of the non-moral virtue of equanimity, his pursuit of a non-moral relationship with a guru, and so on are part of his pursuit of moksa. He pursues these things only in virtue of their relations with moksa. He does not pursue them for their own sakes.

Additionally, as Wolf points out, such bases for the appreciation of things are inherently shallow and contingent. If the sage pursues the relationship with his guru, for example, only as a means to, or as a constituent of the end of mokșa, then he should abandon the relationship when some better but incompatible means or constituent arises, or (perhaps) when mokșa is attained.

This kind of evaluation of relationships presumably undermines the sage's capacity to participate in this (or any) relationship fully, however, and this seems to undermine his ability to live the good life. This concern is only magnified by the repeated claims that the sage is impartial toward friend and foe (Näradaparivrājaka Upanișad 195, Bhagavadgitā 6.9). The same might be true of the sage's merely contingent commitment to the cultivation of non-moral virtues, interests, and so on as well.

All of this suggests that the Hindu sage is precluded from pursuing non-moral virtues, interests, activities, relationships, and so on for their own sakes. His life seems deficient for this reason, even if his single-minded pursuit of mokșa amounts to the single-minded pursuit of a non-moral end. And if it turns out that the Hindu sage forsakes the good life, then any theory of the good life that is derived from his example will be implausible.

\section{A SUPPLEMENT TO THE REPLY TO THE PRECLUDED PURSUITS OBJECTION}

The reply just outlined can be strengthened by adopting the distinction between de dicto and de re motivations. Vanessa Carbonell utilizes this distinction in replying to the Precluded Pursuits Objection as it applies to the moral saint. She points out that sentences like 'A is only motivated to improve the general welfare' are ambiguous. On the one hand, the sentence might be read de dicto, to mean that $\mathrm{A}$ has only one non-derivative motivation - the motivation to improve the general welfare. On this reading, A's motivation to bring about any end other than the improvement of the general welfare is derivative; it is derived entirely from his motivation to improve the general welfare. If $\mathrm{A}$ is motivated to alleviate a particular person's hunger, for example, this motivation is derived entirely from his motivation to improve the general welfare (Carbonell 2009, 390).

Another way to describe A's de dicto motivation to improve the general welfare is to say that the only consideration that $\mathrm{A}$ counts as a direct reason to perform a particular action is the fact that the action will contribute toward improving the general welfare. In the case in which A improves the general welfare by alleviating a particular person's hunger, the fact that A's action will alleviate the person's hunger is only an indirect reason to perform the action. A takes the person's hunger as only 
an indirect reason to act. He is unmotivated by the fact of the person's hunger by itself.

On the other hand, the sentence ' $\mathrm{A}$ is only motivated to improve the general welfare' might be read de re, to mean that $\mathrm{A}$ has a distinct, non-derivative motivation to bring about some or all of the specific ends that he takes to contribute to the improvement of the general welfare. On this reading, if A is motivated to alleviate a particular person's hunger, then he has a non-derivative motivation to alleviate the person's hunger. His motivation to alleviate the person's hunger is not entirely derived from the more abstract motivation to improve the general welfare (Carbonell $2009,390 ; 2011,461)$, even if the more abstract consideration contributes to his motivation. He counts the fact that a person is hungry as a direct reason to alleviate it.

Carbonell argues that Wolf's version of the Precluded Pursuits Objection assumes that the moral saint is motivated to improve the general welfare de dicto, rather than de re. The following passage from Wolf seems to support this interpretation.

[T]here is something odd about the idea of morality itself, or moral goodness, serving as the object of a dominant passion in the way that a more concrete and specific vision of a goal (even a concrete moral goal) might be imagined to serve. Morality itself does not seem to be a suitable object of passion (Wolf 1982, 424, cited at Carbonell 2009, 390; 2013, 462).

Carbonell takes the distinction between "morality itself" and "a concrete moral goal" in this passage to correspond to the distinction between the de dicto and de re readings of the motivation to bring about the general welfare. She concludes that Wolf

seems to think that a moral saint must be motivated by 'morality itself' under that description, as an abstract concept, rather than being motivated directly by those things in the world that the concept picks out, like the relief of suffering (Carbonell 2009, 390).

This interpretation of Wolf seems well supported by Wolf's claim that the moral saint - this time of the utilitarian variety - "values [non-moral virtues, interests, and so on] only because of and insofar as they are a part of the general happiness. He values them, as it were, [only] under the description 'a contribution to the general happiness"' (Wolf 1982, 429, emphasis added).

These quotations also suggest that Wolf takes the claim that the moral saint does not pursue non-moral virtues, interests, activities, relationships, and so on for their own sakes to follow from his single-minded pursuit of the improvement of the general welfare read de dicto. The moral saint pursues non-moral virtues, interests, activities, and so on only in virtue of their relations to the end of improving the general welfare. He does not pursue them for their own sakes, because he does not take himself to have direct reasons to pursue them.

The assumption that the moral saint is motivated to improve the general welfare de dicto, rather than de re, however, seems false. As Michael Smith says in a related context, 
[g]ood people care non-derivatively about honesty, the weal and woe of their children and friends, the well-being of their fellows, people getting what they deserve, justice, equality, and the like, not just one thing: doing what they believe to be right (Smith 1994, 75, cited at Carbonell 2013, 463).

Good people presumably care about improving the general welfare (and/or some other general moral principle). What seems implausible is that the morally best person pursues honesty, justice, the alleviation of hunger, and so on only because of their contributions to the improvement of the general welfare. It seems implausible that the morally best person does not take the fact that some person is hungry as a direct reason to act.

Indeed, it might even be that the moral saint pursues various goals that contribute to the improvement of the general welfare with little to no thought that these pursuits contribute toward improving the general welfare. "In many cases, an agent - even the moral saint - need not be interested in the 'rightness' of her action" per se (Carbonell 2009, 395). This only seems possible, however, if the moral saint counts considerations other than the improvement of the general welfare as direct reasons to act.

There is little doubt that in order for the moral saint to effectively improve the general welfare, he often must have an eye toward this broader goal. This broader consideration, however, might function primarily as a way of "mediating" among those motivations that are already present (Carbonell 2013, 466), rather than as a source for generating more specific motivations. ${ }^{15}$ The moral saint counts the fact that someone is hungry as a direct reason to alleviate the person's hunger, but first reflects on whether alleviating this person's hunger is a sufficiently good way to improve the general welfare. If it is not, then the saint's motivation to alleviate this person's hunger might not prevail. He might not act to alleviate the person's hunger. If it is a sufficiently good way to maximize welfare, however, then the saint acts to do so (at least in part) out of direct concern for the person who suffers from hunger. Hence, the moral saint's motivation to improve the general welfare should be read de re, rather than strictly de dicto. ${ }^{16}$

If the moral saint's motivation to improve the general welfare is read de re, however, then he pursues a much wider range of ends for their own sakes than might be thought. As I said, the person who is motivated to improve the general welfare might have a distinct, non-derivative motivation to bring about each of the specific ends that he takes to contribute to the improvement of the general welfare. So he

\footnotetext{
${ }^{15}$ As Sigrún Svavarsdóttir points out, some derivative motivations might become non-derivative motivations. A person might choose to work with a particular population of people motivated to improve the general welfare, for example, but come to pursue the welfare of these particular people for its own sake (Svavarsdottir 1999, 206, cited at Carbonell 2013, 394).

${ }^{16}$ Carbonell finally claims that the moral saint's motivation to improve the general welfare should be read as both de re and de dicto (Carbonell 2013, 465).
} 
might have direct motivations to alleviate hunger, improve literacy, eradicate tuberculosis, and so on.

The distinction between de dicto and de re motivation is certainly helpful in clarifying the notion of a moral saint. Wolf's failure to explicitly note the distinction, and her assumption that the saint's motivation to improve the general welfare should be read de dicto is a shortcoming in her paper. This is not to say, however, that the distinction resolves Wolf's fundamental objection.

Wolf's fundamental objection, remember, is that the moral saint fails to pursue non-moral virtues, interests, activities, relationships, and so on for their own sakes. One reason to think that Carbonell has not refuted this charge is that the examples that she offers of ends that the moral saint might be directly motivated to pursue are all moral ends. When she considers how a moral saint would answer the question, 'What's your life's passion?' she claims that "the moral saint as I conceive of him would answer with the content of his moral commitments, not the fact that he is so committed. To 'What's your life's passion?' he would answer 'healing the sick' or eradicating tuberculosis"” (Carbonell 2009, 391).

As Carbonell says, healing the sick and eradicating tuberculosis are examples of moral commitments. It is unclear, however, how a more direct commitment to specific, concrete moral goals avoids the charge that the moral saint is precluded from pursuing non-moral virtues, interests, activities, relationships, and so on for their own sakes. All of those ends that the moral saint pursues for their own sakes still might be moral ends, and hence, exclude all non-moral ends. His life might still be deficient for this reason. ${ }^{17}$

This initial concern might be avoided by noting that much of what Carbonell says might apply to non-moral commitments as well. The moral saint who secures the donation to Oxfam by cultivating his golf game, for example, might be directly motivated to improve his golf game independent of its contribution to the general welfare, just as he might be directly motivated to alleviate hunger independent of its contribution to the general welfare. This fact about him might not be part of the description of his moral sainthood. The point, however, is that the moral saint might still be directly motivated to pursue specific non-moral ends. He might be motivated to pursue these ends independent of their relations to the improvement of the general welfare, just as he might be motivated to pursue moral ends independent of their relations to the improvement of the general welfare. So when he pursues these nonmoral ends, he might be both directly and indirectly motivated to do so. He might pursue them (at least in part) for their own sakes.

\footnotetext{
${ }^{17}$ Carbonell seems to think that it is enough to prove that the moral saint is motivated to pursue individual moral goals. "[A] moral saint whose life is 'dominated by the motivation to be moral' is much less unattractive when we interpret this motivation as being toward doing morally good things de re rather than solely de dicto" (Carbonell 2009, 392). This seems to misidentify the fundamental objection, however. The fundamental problem with the life of the moral saint is not that he is "annoying or fanatical" (Carbonell 2009, 392), but that he is unable to whole-heartedly pursue nonmoral virtues, interests, activities, relationships, and so on for their own sakes.
} 
It might be objected that the person who best improves the general welfare by developing his golf game is a rarity. Most people do not best improve the general welfare by pursuing non-moral virtues, interests, relationships, and so on. As Carbonell points out in her example of Paul Farmer, however - whom she takes to be a living moral saint - the moral saint's activities tend to involve the pursuit of a wide range of ends. Farmer travels extensively, learns foreign languages, studies different religious traditions and mythologies, and so on (Carbonell 2009, 378). If he pursues these things at least in part for their own sakes, then it is not the case that he fails to pursue non-moral virtues, interests, activities, relationships, and so on.

This adapted reply from Carbonell still seems problematic, however. Even in those cases in which the moral saint actually pursues non-moral ends for their own sakes, his pursuit of any non-moral end remains entirely contingent on the relations between the specific non-moral end and the further (or broader) end of improving the general welfare. His motivation to cultivate his golf game might not derive entirely from his motivation to improve the general welfare, but the moral saint seems committed to allowing the former to move him only when it is a means to improving the general welfare. Once the non-moral virtue, interest, activity, or relationship no longer contributes sufficiently to the end of improving the general welfare, then, the moral saint must abandon it. Farmer must abandon his study of French as soon as he can best serve the general welfare in a non-French speaking country.

As I mentioned above, this kind of contingency in a person's commitments undermines his ability to participate in them fully. This seems most startling in the example of a personal relationship (where it seems to preclude close personal relationships altogether), but it applies to other pursuits as well. A life in which every pursuit of a non-moral end is contingent in this way seems deficient.

Carbonell might reply to these concerns by pointing out that they assume that the moral saint always acts to maximize the general welfare. As she convincingly argues with the example of Paul Farmer, however, people are often counted as moral saints even though they do not always act to maximize the general welfare (Carbonell 2009, 378).

If a moral saint need not always act to maximize the general welfare, then his commitments to non-moral ends might be less contingent. He might maintain a nonmoral personal relationship, for example, even after it ceases to be a means to improving the general welfare, just because he is not committed to improving the general welfare with every action he performs (Cf., Adams 1984, 396). Farmer might continue to master French, even though it does not contribute to the improvement of the general welfare.

It is open to Wolf to reply to these kinds of considerations, however, by insisting that people like Farmer do not fully meet the moral ideal that common sense and western moral theories entail. The fact that ordinary language does not track this conception of moral sainthood is hardly a reply to this charge (Perrett 1998, 32).

Alternatively, Wolf might admit that Farmer is a moral saint, but insist that common sense and western moral theories count a person who better maximizes welfare as even more praiseworthy. If the life of this most praiseworthy person is 
deficient, however, then the ideal that common sense and western moral theories endorse is not worth pursuing.

The distinction between de dicto and de re motivation is much more helpful, however, in avoiding the Precluded Pleasures Objection to Hindu sage ideals. If the Hindu sage's motivation to pursue mokșa is understood de re rather than de dicto, then he might be directly motivated to pursue each of those ends that contribute to the attainment of mokșa. Unlike in the case of the moral saint, however, most of the more specific ends that the sage pursues are non-moral ends - in part because the goal of moksa is itself a non-moral end.

A householder remains embedded in a close-knit community that includes parents, spouse, children, and friends. He pursues a vocation, maintains an active religious life - in the form of ritual and devotional practices - has time to pursue hobbies, indulge in diversions, and so on. The same might be true of the karmayogin, who continues to perform his varnāśramadharma (obligations in virtue of class and life stage), but in a spirit of renunciation. ${ }^{18}$

Many of these ends might be understood as non-moral ends. Hence, the karmayogin might pursue a wide range of non-moral ends that include non-moral virtues, activities, interests, relationships, and so on. If he pursues these things for their own sakes - as the de dicto/de re distinction makes possible - then he pursues non-moral virtues, interests, activities, relationships, and so on for their own sakes.

In this case, however, there is little reason to think that the demand to pursue mokșa will make his pursuit of these non-moral ends highly contingent, in the way that the moral saint's pursuit of the general welfare makes his pursuit of specific nonmoral ends highly contingent, since the karmayogin can remain committed to these activities for the duration of his life. There are no obvious scenarios in which the two must conflict.

Moreover, the karmayogin seems required to pursue career, devotional practices, strong family relationships, and so on. The pursuit of these things is part of what

\footnotetext{
${ }^{18}$ A reviewer for Comparative Philosophy raises questions about whether the karmayogin can really pursue hobbies for their own sakes. I assume here that the pursuit of hobbies and diversions is a normal component in the life of the householder. If the karmayogin is, in principle, indistinguishable - at least on the surface - from the dutiful householder, then presumably the pursuit of hobbies and diversions is part of the life of the karmayogin as well. If the pursuit of hobbies and diversions is part of his life as a householder, then it is consistent with his single-minded pursuit of mokssa, in the sense that these pursuits are not obstacles to his attainment of mokșa. If this is right, then there is little reason to think that he must pursue hobbies and diversions only in virtue of their contribution to the attainment of mokșa, just as there is little reason to think that the moral saint must cultivate his golf game only as means to improving the general welfare. The karmayogin might, instead, pursue these things for their own sakes.

There might, again, be other reasons - like the sage's supposed desirelessness - that preclude the karmayogin from pursuing hobbies and diversions for their own sakes. This, however, is an issue that I have already set aside (see section three above).

Finally, the second clarification that I offered in section three above implies that neither the karmayogin nor the samnyāsin need pursue hobbies or diversions in order to live the good life. The karmayogin might live the good life despite being precluded from the pursuit of hobbies and diversions for their own sakes, so long as he pursues other relevant non-moral ends for their own sakes.
} 
makes him a karmayogin. These ends are at least partly non-moral, just because they benefit the karmayogin himself. Hence, the karmayogin's pursuit of certain nonmoral virtues, interests, activities, relationships, and so on are necessary, rather than contingent. $^{19}$

The samnyāsin lives a much more austere life than the karmayogin does. He still pursues a wide range of non-moral ends, however. He pursues equanimity, meditation, concentration, knowledge of ultimate reality, solitude, and so on. ${ }^{20}$ Hence he pursues at least some of those non-moral ends, the pursuit of at least some of which is essential to the good life. Again, the de dicto/de re distinction makes it possible for him to pursue these things for their own sakes.

Furthermore, his commitments are not contingent in the way that the moral saint's commitments seem to be either, since the relations between these things (such as equanimity, and so on) and moksa are necessary and enduring, rather than contingent. The samnyāsin cultivates equanimity, for example, until he attains moksa (as does the karmayogin). Once he attains moksa, he exhibits this virtue as long as he remains embodied. To be perfectly equanimous in this way is simply part of what it is to be liberated. The same is true of many of the other virtues and pursuits of the samnyassin that I mentioned above. ${ }^{21}$

This suggests that both the samnyāsin and the karmayogin might pursue some of those ends the pursuit of which seems essential to the good life. Furthermore, they might pursue these ends for their own sakes, independent of their relations with the end of mokșa, and in a way that is not highly contingent on circumstances. This

\footnotetext{
${ }^{19}$ My thanks to an anonymous reviewer for Comparative Philosophy for pushing me on this point. It is worth noting, however, that this conclusion is stronger than it has to be. It is enough that the karmayogin's non-moral pursuits are consistent with his pursuit of mokșa. This, by itself, allows him to fully commit to their pursuit. They need not be necessary means or constituents of mokșa.

${ }^{20}$ In the case of the samnya $\overline{a s i n}$, there might still be questions about whether the range of his pursuits is sufficiently broad. I think they are, but more might be said on this matter.

${ }^{21}$ It might be tempting to think that the same reply is available in the case of the moral saint. Indeed, Wolf says that the moral saint "must have and cultivate those qualities which are apt to allow him to treat others as justly and kindly as possible... He will be patient, considerate, even-tempered, hospitable, charitable in thought as well as in deed" (Wolf 1982, 421). If the moral saint must pursue these qualities, however, then his commitment to them is not highly contingent. If he can also pursue them for their own sakes - in light of the de dicto/de re distinction - then there might be some sense in which these virtues are at least partly non-moral. This suggests that the moral saint can at least pursue non-moral virtues for their own sakes in a way that is not highly contingent.

Even the saint's pursuit of these virtues, however, turns out to be highly contingent, just because the virtues that might be useful in promoting the general welfare are highly variable. It is hard not to think that the moral saint must be saintly in standard ways that involve patience, benevolence, and so on. For any virtue on this list, however, there might be circumstances in which the virtue must be abandoned. Indeed, the common objection that maximizing consequentialist analyses of right action make anything permissible seems to entail not only that any virtue might be counter-productive to improving the general welfare, but also that any vice might be required. If a moral saint might maximize welfare by playing golf, performing brain surgeries, managing a large charity organization, or smuggling refugees across borders, and if the optimum activity might change due to changing circumstances, then it is hard to see how the moral saint might be fully committed to the pursuit of any specific range of non-moral virtues.
} 
means that they can fully commit to the pursuit of these ends in the way that Wolf seems to say one must in order to live the good life - and in a way that the moral saint cannot. If this is right, then the Hindu sage is not subject to the Precluded Pursuits Objection. This leaves open the possibility that the sage's life is not only good for him, but exceedingly good for him, and hence, that a plausible theory of the good life might be derived from his example.

One lingering question here has to do with the initial claim that the Hindu sage pursues mokșa single-mindedly. It should be clear at this point that this characterization of the sage is at least ambiguous. On the one hand, the claim might be read to mean that the sage thinks only of mokșa in acting, in the sense that his exclusive intention is the attainment of mokșa. Indeed, with this sense of the claim in mind, the Precluded Pursuits Objection seems to apply to the sage straightforwardly. If his exclusive intention is the attainment of mokșa, then surely he does not pursue other ends for their own sakes in acting.

If the sage is motivated to pursue ends other than moksa for their own sakes, however, then the sage does not single-mindedly pursue moksa in this sense. Indeed, there might be cases in which the sage thinks nothing at all of mokșa, even as he acts in a way that contributes to its attainment, just as the moral saint might not think of improving the general welfare per se, even as he acts in a way that improves the general welfare.

The claim that the Hindu sage pursues mokșa single-mindedly might instead be taken to mean that everything the sage does contributes to his attainment of moksa. In this sense, the claim might be true. This reading, however, does not preclude the sage from pursuing other ends - including non-moral virtues, interests, and so on - for their own sakes, as long as these pursuits are consistent with his pursuit of mokșa. And since, for both the samnyyassin and the karmayogin, some pursuits of this sort are not only consistent with the pursuit of moksa, but essential to it, neither ideal is subject to the Precluded Pursuits Objection.

\section{CONCLUSION}

Since many Hindu texts and traditions claim that the Hindu sage lives an exceedingly good life, it makes sense to assume, at least initially, that they take a life to be good for the person whose life it is more generally insofar as it exemplifies those characteristics that make the sage's life good for the sage. If this is right, then it might be relatively simple to infer a theory of the good life from Hindu conceptions of sagehood.

Someone might doubt that the Hindu sage lives the good life in the first place, however, on the grounds that his single-minded pursuit of the moral end of moksa precludes his pursuit of non-moral virtues, interests, activities, and so on for their own sakes. Since the Hindu sage's goal of mokșa is at least partly a non-moral end, however, and since the sage might pursue those other non-moral ends that contribute to the end of moksa - including non-moral virtues, interests, activities, and so on - for their own sakes, in a way that is not subject to a high degree of contingency, Hindu 
sage ideals avoid the Precluded Pursuits Objection, even if western moral saint ideals do not. This leaves open the possibility that the Hindu sage's life is not only good, but exceedingly good, and hence, that a plausible theory of the good life might be derived from his example.

\section{ACKNOWLEDGEMENTS}

My thanks to Stephen Harris for feedback on previous versions of this paper. Thanks also to two anonymous referees at Comparative Philosophy for suggestions that strengthened the paper.

\section{REFERENCES}

\section{Sanskrit Texts}

Bhagavadgìtā, in Sadhale (2010).

Brhat-Samnyāsa Upaniṣad, in Schrader (1912).

Paramahamsaparivrājaka Upaniṣad, in Schrader (1912).

Nāradaparivrājaka Upanișad, in Schrader (1912).

Yogaśāstra, in Sarvabhauma and Nyayaratna (1970).

\section{Edited Volumes of Sanskrit Texts}

Sadhale, Shastri G. S. (ed.) (2010), The Bhagavad-Gìtā with Eleven Commentaries (Delhi: Parimal Publications).

Sarvabhauma, Darsanik and Nyayaratna, Sahityadarsanadhyacharya T. (ed.) (1970), The Sānga Yogadarśana or Yoga Darśana of Patañjali with the Scholium of Vyāsa and the Commentaries - Tattva Vaiśārdi, Patañjala Rahasya Yogavārtika and Bhāsvati of Vācaspati Miśra, Raghavānanda Sarasvatī, Vijñāna Bhikṣu and Hariharānanda Aranya (Varanasi: Chaukhambha Sanskrit Bhawan).

Schrader, F. Otto (ed.) (1912), The Minor Upaniṣads Vol. 1: Saṃnyāsa Upaniṣads (Madras: Adyar Library).

\section{Texts in English}

Adams, Robert M. (1984), "Saints”, The Journal of Philosophy, 81 (7): 392-401. Bailey, Gregory. (1985), Materials for the Study of Ancient Indian Ideologies: Pravrtti and Nivrtti (Torino, Italy: Indologica Taurinensia).

- (1983), "Suffering in the Mahābhārata: Draupadī, Yudhișthira", in Kapil N. Tiwari (ed.) Suffering: Indian Perspectives (Delhi: Motilal Banarsidass), 38-60.

Burghart, Richard (1983), "Renunciation in the Religious Traditions of South Asia", Man, 18 (4): 635-53. 
Carbonell, Vanessa (2009), "What Moral Saints Look Like", Canadian Journal of Philosophy, 39 (3): 371-398.

- (2013), "De Dicto desires and morality as fetish", Philosophical Studies, 163 (2): 459-77.

Cullity, Garrett (2009), "Demandingness and Arguments from Presupposition", in Timothy Chappell (ed.) The Problem of Moral Demandingness: New Philosophical Essays (London: Palgrave Macmillan).

Dumont, Louis (1966), Homo Hierarchicus: An Essay on the Caste System (Paris: Gallimard).

Feldman, Fred (2004), Pleasure and the Good Life: Concerning the Nature, Varieties, and Plausibility of Hedonism (Oxford: Oxford University Press).

Fort, Andrew (1998), Jivvanmukti in Transformation: Embodied Liberation in Advaita and Neo-Vedanta (Albany: SUNY Press).

Framarin, Christopher G. (2009), Desire and Motivation in Indian Philosophy (London/New York: Routledge).

Goodman, Charles (2009), Consequences of Compassion: An Interpretation and Defense of Buddhist Ethics (Oxford: Oxford University Press).

Harris, Stephen (2014), Demandingness, Self-Interest and Benevolence in Śāntideva's Introduction to the Practice of Awakening (Bodhicaryavatara), Dissertation, University of New Mexico.

Hill, Peter (2008), "Pravrtti and Nivrtti Sages in the Mahābhārata", Australian Journal of Politics and History, 35 (3): 319-37.

Hooker, Brad (2009), "The Demandingness Objection”, in Timothy Chappell (ed.) The Problem of Moral Demandingness: New Philosophical Essays (London: Palgrave Macmillan).

Maas, Philip (2013), "A Concise Historiography of Classical Yoga Philosophy", in Eli Franco (ed.) Historiography and Periodization in Indian Philosophy (Vienna: Verein Sammlung de Nobili : Institut für Südasien-, Tibet- und Buddhismuskunde der Universität Wien).

Perrett, Roy W. (1998), Hindu Ethics: A Philosophical Study (Honolulu: University of Hawaii Press).

Railton, Peter (1984), “Alienation, Consequentialism, and the Demands of Morality", Philosophy and Public Affairs, 13 (2): 134-171.

Svavarsdóttir, Sigrún (1999), "Moral Cognitivism and Motivation”, Philosophical Review, 108 (2): 161-219.

Smith, Michael (1994), The Moral Problem (Oxford: Blackwell).

Whicher, Ian (1998), The Integrity of the Yoga Darśana: A Reconsideration of Classical Yoga (Albany, NY: SUNY Press).

Williams, Bernard (1963), "A Critique of Utilitarianism" in J. J. C. Smart and Bernard Williams, Utilitarianism for and against (Cambridge: Cambridge University Press).

Wolf, Susan (1982), "Moral Saints”, The Journal of Philosophy, 79 (8): 419-39. 